\title{
Predicting the intensity of wind-blown removal of dust and sand in the Turkmenistan desert
}

\author{
V. Kostiukovsky ${ }^{1} \&$ A. Arnageldyev ${ }^{2}$ \\ ${ }^{I}$ Albert Katz Department of Dryland Biotechnologies, \\ Jacob Blaustein Institutes for Desert Research, \\ Ben-Gurion University of the Negev, Israel \\ ${ }^{2}$ Turkmenian Institute of Transport, Ashgabat, Turkmenistan
}

\begin{abstract}
Wind plays a major part in the dynamics of solid non-organic material in the deserts of Turkmenistan. The main direction of movement of sand and dust in this region, due to atmospheric transference, is from north to south.

Data from the literature and the results of field investigations testify that the majority of wind-blown material comes from desert dunes without vegetation (combined area $37,000 \mathrm{~km}^{2}$ ) - more than 29 billion tons per year. Material blown from sandy desert terrain anchored by vegetation $\left(206,000 \mathrm{~km}^{2}\right)$ amounts to 16.5 billion ton/year. Nine hundred and sixty million ton/year comes from the saline plains $\left(20,000 \mathrm{~km}^{2}\right)$, where the surface is crumbly due to intensive geo-chemical processes, and 352 million ton/year from stony rubble surfaces $\left(45 \mathrm{~km}^{2}\right)$. Consequently, nearly 50 billion ton/year of sand and dust are implicated in windblown solid particle removal in the deserts of Turkmenistan.

The influence of human activity in the deserts during the 20th century came close to being catastrophic. More than $60 \%$ of the territory of Turkmenistan $\left(200,000 \mathrm{~km}^{2}\right)$ is currently undergoing desertification. More and more dust and sand is blown from overgrazed pastures, roads, arable fields, settlements, etc. The major sources of the blown sand, dust and salts are the exposed beds of the Aral Sea and other water bodies that are drying up after extraction of their water for irrigation (nearly $45,000 \mathrm{~km}^{2}$ ).

Natural warming of the climate is intensified by the hotbed effect, in which increased human activity has led to an increase in average annual air temperatures by $6-9{ }^{\circ} \mathrm{C}$ and an abatement of precipitation by $50 \%$. The result may be expansion of desertification to $90 \%$ of the deserts of Turkmenistan, and an increase in the quantity of wind-blown sand and dust to 65 billion ton/year by 2050.
\end{abstract}

Keywords: wind-blown transportation, soil types, Turkmenistan Desert, desertification, solid substrate. 


\section{Introduction}

Wind-blown transportation of dust and sand plays a major role in the movement of solid non-organic material in the desert zone, including the deserts of Central Asia and particularly in the extra-arid desert of Turkmenistan (where evaporation capability exceeds atmospheric precipitation by 100:1). The intensity and spread of desertification due to both natural causes and increasing human pressures (Alternative Strategy [1]; Mabbutt and Wilson [2]; UNCCD [3]) contribute to such wind-blowing activity.

The direction of movement of blown material depends on the atmospheric circulation. The major movement of air masses in the desert of Turkmenistan is from the northern part of the horizon (N, NW, NE) to the southern part. Consequently, most blown material travels in a southerly direction, which is indicated by the orientation of the sandy relief forms. By determining the quantity of material involved in the wind-blown process as a result of different environmental conditions, we can calculate a future change in this quantity, related to natural changes in climate and human influence.

\section{Materials and methods}

The quantity of the blown and transported dust and sand by wind has been investigated in the literature (e.g. Thomas [4]; Fedorovich [5]; Arnageldyev [6]; Bagnold [7]), using data from the hydro-meteorological service and from field investigations. The transportation of blown material in the field was defined using standard dust- and sand-catchers, catch pits, scotch-tapes etc. The change in soil surface beneath the wind-blown process was measured by continuous monitoring using geodesical instruments along fixed profiles in different soil types (sandy, loamy, stony, salty, etc.), and by continuous monitoring of metal and wooden rulers, inserted into the same substrates. Additional methods of investigation included measuring the extent of wind-blowing of desert plants, roads, buildings, archaeological remains, etc. Areas with different surface types were defined using topographical, soil and geomorphological maps and space information from various years.

\section{Results}

Five types of soil surface were defined by their resistance to wind erosion: bare sand with no vegetation, sandy soil anchored by vegetation, loamy soil, stonyrubble soil and saline plains (Fig. 1). The major source of blown dust and sand in the area is the sandy dunes with no vegetation. Some of this is natural in origin, i.e. places with minimal precipitation and very strong winds, at the seashore, etc. These types of soils are found on the shores of the Caspian Sea, mainly near Cheleken peninsula, in the narrow windy passes between the Large and Small Balkhan Mountains, along the Amudarya River, in part of the Amudarya valley, near the border of the mountains and plain, and in some places in the central part of the Karakum desert. 
Apart from the above natural sources of sand and dust, many desert dunes have been formed under continuous human pressure from the prehistoric period (Neolithic remains, visible even today) until the present (oases, wells, settlements, industrial and mining regions, railways, highways, etc.). It is very difficult to identify dust and sand blown from desert dunes due to the constant exchange of particles in the wind. A detailed analysis of topographical maps allowed us to determine the layer of soil blown up from dune sites as $10-50 \mathrm{~cm}$ per year. The area of sand without vegetation in the desert of Turkmenistan covers $37,000 \mathrm{~km}^{2}$, yielding almost 29,600 billion tons of solid material per year (Table 1).

Table 1: The quantity of solid non-organic material blown up in the desert of Turkmenistan.

\begin{tabular}{|l|l|l|l|}
\hline Soil surface type & $\begin{array}{l}\text { Area } \\
\left(1000 \mathrm{~km}^{2}\right)\end{array}$ & $\begin{array}{l}\text { Average thickness } \\
\text { of layer of blown } \\
\text { material } \\
(\mathrm{mm} / \text { year })\end{array}$ & $\begin{array}{l}\text { Total quantity of } \\
\text { wind-blown } \\
\text { material } \\
\text { (billion } \\
\text { tons/year) }\end{array}$ \\
\hline $\begin{array}{l}\text { Sands without } \\
\text { vegetation }\end{array}$ & 37 & $100-500$ & 29,600 \\
\hline $\begin{array}{l}\text { Sands anchored by } \\
\text { vegetation }\end{array}$ & 206 & $3-10$ & 16,480 \\
\hline Loamy soil & 45.5 & $1-5$ & 288 \\
\hline Stony-rubble soil & 44.3 & $1-7$ & 352 \\
\hline Saline plains & 20 & $10-50$ & 960 \\
\hline Total & $\mathbf{3 5 2 . 8}$ & & $\mathbf{4 7 , 6 8 0}$ \\
\hline
\end{tabular}

The layer of blown soil in the sandy desert anchored by vegetation is less than the layer of blown soil in the bare sands, though the area covered by anchored sands is five times greater. The measurements show that the change in surface thickness in sands covered by grass and shrubs is not more than $1 \mathrm{~cm}$ per year. Most of the dust and sand carried by the wind falls in wind shade of plants and is anchored by stems, roots and other products of plant activity. The vegetationcovered areas in Turkmenistan cover the largest part of the desert (more than $200,000 \mathrm{~km}^{2}$ ), while the quantity of substance blown up from there is less than from the bare sands (16,480 billion tons per year). Dust is the predominant substance blown from the anchored sands, in contrast to the bare sands where, over thousands of years of dune shifting, much of the dust has been carried off by the wind.

The dust is mainly material blown from loamy surfaces. This type of desert soil is mainly found in the foot-hills of the Kopet-Dag and Balkhan Mountains, in the Tedjen and Murgab River deltas, which do not reach the sea, and in the Atrek River, which reaches the Caspian Sea only in wet winter/spring periods. Many loamy surfaces ("takyrs") are typical of the drops found amongst dunes and ridges in the sandy desert (Fig. 1). 


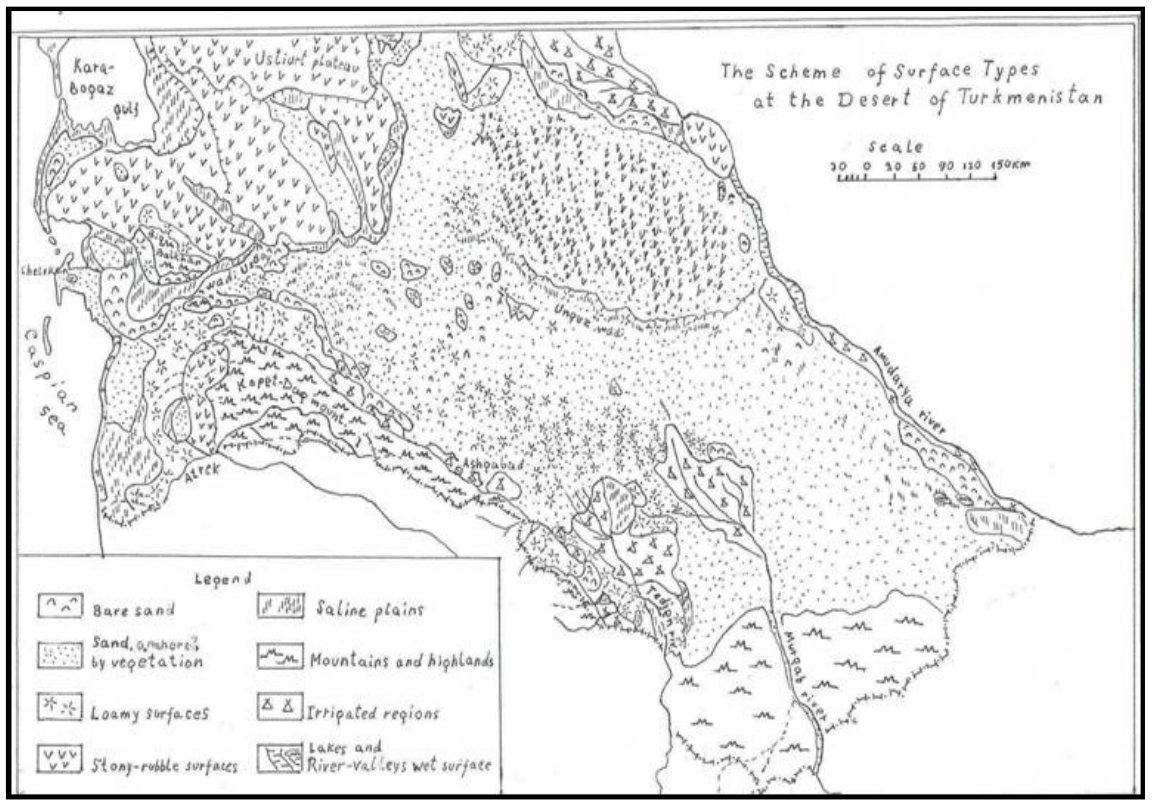

Figure 1: Scheme of surface types in the desert of Turkmenistan.

The loamy soil possesses great adhesive strength and is resistant to being blown away by the wind. Due to the admixture of sandy, dusty and alevrite particles with clayey and loamy ones, and human and animal activity which destroys the surface, the wind blows up a layer of loam between $<1 \mathrm{~mm}$ and $5 \mathrm{~mm}$ thick per year. As a result, only 288 billion tons per year are blown from $45,500 \mathrm{~km}^{2}$ of loamy surfaces.

Stony-rubble desert occupies mainly the north-western part of Turkmenistan - from the Kara-Bogaz gulf to Sarykamysh Lake and Wadi Uzboy. The total area is nearly $44,300 \mathrm{~km}^{2}$. Continued intensive destruction of stony highlands by wind, water, temperature contrasts, and plant, animal and human activity constantly produces new quantities of sand, dust and rubble which involved in the process of wind erosion. Thus from an area of $44,300 \mathrm{~km}^{2}$ of stony-rubble desert, the wind blows up more than 352 billion tons of dust, sand and rubble per year (Table 1).

One of the most active sources of blown material is saline soil. Large quantities of such soil occur near the south-eastern shores of the Caspian Sea, in the foot-hills of the Ustiurt plateau, in the dry wadis Uzboy and Unguz, in the Murgab and Tedjen River deltas and in the isolated drops between sandy ridges. Saline plains, formed under human influence, are typical of areas containing irrigated fields, canals, water bodies etc. These large areas of saline plains have been exposed during the drying up of the Aral Sea. The soils in the saline plains are chemically active, due to the large quantity of salts they contain which break up the surface. Particles of broken up sand, dust and loam are blown up from the salty plains by the wind. The total area covered by saline plains is less than the 
other soil surface types (nearly $20,000 \mathrm{~km}^{2}$ ), but the quantity of material blown up from these soils is more than that blown up from the loamy and stony soils together -960 billion tons per year (Table 1).

We can see that the total quantity of solid non-organic material blown up in the desert of Turkmenistan is between 45 and $50 \times 10^{9}$ tons per year. Most of the blown material is carried in the lower layers of wind flow, and is dropped at a distance of several centimetres to hundreds of meters from its origin. Thus the material moves with the wind within the borders of the Turkmenistan desert. At the same time however, particles with a diameter of less than $0.25 \mathrm{~mm}$ can fly with the wind upward to an altitude of $4-10 \mathrm{~km}$ and be carried hundreds and thousands of kilometres. Dust particles from the Sahara and Sahel Deserts have been located in the island of Barbados (Kovda [8]). The reddish dust from Sahara that fell during the years 1970-1980 reached Ashgabat and formed a layer up to $10 \mathrm{~cm}$ thick in the streets.

The average content of small particles which are present in wind flows over all surface types is $0.5-1 \%$ (our measurements and data from the literature). This allows us to put the quantity of solid material transported out of the Turkmenistan desert at 220-250 billion tons per year.

The development of future wind erosion will depend on several global and local factors:

1. Global warming due to the hotbed effect, which will increase aridity in desert zones.

2. Increasing human activity, including upsetting of the natural equilibrium.

All of these factors are causes of desertification, the scale of which is now universal. In the desert of Turkmenistan the consequences of desertification will be an enlargement of the area occupied by sandy dunes without vegetation, destruction of soils by cattle, railways, vehicles, industry and construction, etc.; increase in soil salinisation from irrigation, construction of canals, water bodies, etc.; reduction in river flow rates and drying up of lakes.

Bare sands will be formed in the sandy desert - around roads, settlements, industrial sites, areas of cattle concentration, at the dry beds of the Aral Sea and many lakes and water bodes in its vicinity. Accurate prediction of such a process is not possible, because many of the causes develop very slowly, but the current trend enables us to quantify the enlargement of the bare sand area at 350-500 $\mathrm{km}^{2}$ annually, and blowing up of sand and dust at between 3000 and 5000 billion tons per year (Table 2).

As the area of bare sand enlarges, it takes place of the anchored sands, whose area decreases correspondingly. As a result, the removal of sand and dust from the anchored soils falls every year by $150-300$ billion tons.

The area covered by saline soils grows very rapidly under intensified irrigation, increased water use for industry and domestic purposes and the disposal of wastewater into the desert. Nearly $30,000 \mathrm{~km}^{2}$ of saline plains appeared outside the borders of Turkmenistan in the dry bed of the Aral Sea, and several thousand sq. km appeared inside Turkmenistan around the Aral region. Thus the area covered by saline plains is increasing rapidly and this trend may be 
set to continue for quite a while. Moreover, not only are dust and sand blown up into the atmosphere from these saline areas, but also billions of tons of salts.

Table 2: $\quad$ The change in quantity of solid non-organic material blown up in the desert of Turkmenistan under conditions of desertification.

\begin{tabular}{|c|c|c|c|c|c|c|}
\hline \multirow[t]{2}{*}{$\begin{array}{l}\text { Soil } \\
\text { surface } \\
\text { type }\end{array}$} & \multirow{2}{*}{$\begin{array}{l}\text { Area } \\
\text { in } \\
\text { year } \\
2000 \\
(1000 \\
\left.\mathrm{km}^{2}\right)\end{array}$} & \multirow{2}{*}{$\begin{array}{l}\text { Quantity of } \\
\text { material blown } \\
\text { up from } 1000 \\
\mathrm{~km}^{2} \\
\text { (billion } \\
\text { tons/year) }\end{array}$} & \multirow[t]{2}{*}{$\begin{array}{l}\text { Change in area, } \\
\left(1000 \mathrm{~km}^{2} /\right. \\
\text { year) }\end{array}$} & \multicolumn{3}{|c|}{$\begin{array}{l}\text { Quantity of material blown } \\
\text { up } \\
\text { (billion tons/year) }\end{array}$} \\
\hline & & & & $\begin{array}{l}\text { Year } \\
2000\end{array}$ & $\begin{array}{l}\text { Year } \\
2010\end{array}$ & $\begin{array}{l}\text { Year } \\
2020\end{array}$ \\
\hline $\begin{array}{l}\text { Sands } \\
\text { without } \\
\text { vegetation }\end{array}$ & 37 & 800 & $+0.3-0.5$ & 29,600 & 32,800 & 33,600 \\
\hline $\begin{array}{l}\text { Sands } \\
\text { anchored } \\
\text { by } \\
\text { vegetation }\end{array}$ & 206 & 80 & $-0.3-0.5$ & 16,480 & 16,240 & 16,080 \\
\hline $\begin{array}{l}\text { Loamy } \\
\text { soil }\end{array}$ & 45.5 & 6.3 & - & 288 & 409.5 & 500.5 \\
\hline $\begin{array}{l}\text { Stony- } \\
\text { rubble } \\
\text { soil }\end{array}$ & 44.3 & 8 & - & 352 & 443 & 531.6 \\
\hline $\begin{array}{l}\text { Saline } \\
\text { plains }\end{array}$ & 20 & 48 & $+0.2-0.4$ & 960 & 1104 & 1152 \\
\hline Total & 352.8 & - & - & 47,680 & 50,194 & 51,864 \\
\hline
\end{tabular}

The change in areas covered by loamy and stony-rubble deserts is minor (some settlements, industrial sites, irrigated fields, water bodes), but they are exposed to pressure from development of large roads, railways and off-road vehicles, and the soils are destroyed during construction of pipelines, powerlines, etc. This disturbance in the surface consequently leads to an increase in the layer that is exposed to the wind in industrial regions - up to $10-15 \mathrm{~cm}$, and windblowing of this layer increases from 6-8 billion tons per year per $1000 \mathrm{~km}^{2}$ to 8 12 billion ton per year.

Under such desertification processes the total quantity of wind-blown sand and dust in the desert of Turkmenistan, now ranging from $45-50 \times 10^{9}$ ton/year, may reach $47-53 \times 10^{9}$ ton by the year 2010 and $49-54 \times 10^{9}$ by the year 2020 . Strategies for regulating wind erosion and importation of dust and sand to the atmosphere are being jointly worked out by international programs for combating desertification (Alternative Strategy [1] and others). They include regulation of grazing, ceasing the use of off-road vehicles, promotion of progressive methods of water use and soil cultivation, reduction in the quantity of wastewater, industrial and domestic effluents. Afforestation of destroyed lands and preservation of natural and man-made vegetation as a means to combating wind-erosion are especially important. 


\section{Conclusion}

Wind-blown erosion plays a major role in the arid regions of the world, including the extra-arid desert of Turkmenistan. The largest quantities of sand and dust (296,000 billion tons per year) are blown from the desert dunes with no vegetation, and the smallest quantities (288 billion tons per year) from loamy surfaces, due to the great strength of adhesion between shallow particles in the soil.

All soil surface types present in the Turkmenistan Desert together supply the atmosphere with $45-50 \times 10^{9}$ tons of dust and sand per year. Most of this falls inside the desert of Turkmenistan, and only 220-240 billion tons of particles with diameter less than $0.25 \mathrm{~mm}$ are carried out to other regions annually in the upper layers of atmosphere.

The process of desertification under climatic changes and intense anthropogenic pressures leads to more active wind erosion and enlargement of areas covered by bare sands and saline soils. The result of this process will be an increase in wind-blown removal of dust and sand to $47-53 \times 10^{9}$ ton by the year 2010 and to $49-54 \times 10^{9}$ ton by the year 2020. Thus we may expect an increase in the quantity of solid non-organic material present in the lower layers of the atmosphere in Turkmenistan.

Implementation of rational measures for combating desertification will lead to a mitigation of the negative consequences of wind erosion.

\section{References}

[1] Alternative Strategy for Desert Development and Management. Proc. Int. Conf. Sacramento, California, 1977, V.1-4, New York, e.a. I-X, 1982.

[2] Mabbutt, J.A. \& Wilson, A.W., (eds). Social and Environmental Aspects of Desertification. International Geographical Union / The United Nations University, 40 p., 1980.

[3] UNCCD, Desertification. An Overview (A/Conf/74/1). Background Document, UN Conference on Desertification, Nairobi, Kenya, 1977.

[4] Thomas, D.S.G. Arid geomorphology. Progr. Phys. Geogr. 12(4), pp. 595-606, 1988.

[5] Fedorovich, B.A., Dynamics and Statute of Relief-Forming in Deserts. Nauka: Moscow, 236 p., 1983.

[6] Arnageldyev, A., The Sands of Central Part of Karakum Desert, their Mobility and Struggle Against it. Ylum: Ashgabat, 120 p. (in Russian), 1979.

[7] Bagnold, R.A. The Physics of Blown Sands and Desert Dunes. Methuen: London, 265 p., 1954.

[8] Kovda, V.A., The Aridisation of Dryland and Struggle against Drought. Nauka: Moscow, 272 p., 1977. 